\title{
INFORMATION AND ANALYTICAL SUPPORT OF PUBLIC ADMINISTRATION IN THE FIELD OF INSURANCE
}

\begin{abstract}
Oleksandr Zaiets ${ }^{1}$, Karen Ismailov ${ }^{2}$
${ }^{1}$ Ph.D. (Law), Associate Professor, Professor of the Department of Cybersecurity and Information Support of Odesa State University of Internal Affairs, Odesa, Ukraine, e-mail: zaec_1985@meta.ua, ORCID: https://orcid.org/0000-0002-4426-5241

${ }^{2}$ Ph.D. (Law), Associate Professor, Head of the Department of Cybersecurity and Information Support of Odesa State University of Internal Affairs, Odesa, Ukraine, e-mail: 0997060070@ukr.net, ORCID: https://orcid.org/0000-0001-5137-2507
\end{abstract}

The article is devoted to the issues of information support of public administration in the field of insurance, change its role in the context of administrative reform and implementation of European principles and standards of public administration. The study focuses on the study of the features of administrative and legal means of public administration, necessary for the regulation of relations between the subject's insurance market and other participants in insurance relations. As a result of scientific research, the authors determined that public administration in the field of insurance, being an important part of public administration, performs regulatory, control and organizational, informative functions in the insurance sector, thus ensuring the sustainable development of insurance activities, as well as in general promoting the democratic development of the state and society at the level of European standards.

The key trend of the beginning of the third millennium is the transition of mankind to the era of information society, accompanied by an unprecedented growth of the role of information and knowledge in all spheres of society in general and in public administration in particular. The world information space has already been formed, which determines new forms of social relations and management, mass communication and interaction, way of life and way of thinking. There is an active shift and complication of various and diverse social processes that are beginning to interact with each other and flow into the global information space as elements of the global network structure of mankind.

New paradigms of culture, economy, and public administration are emerging. In such conditions, the problem of conceptual rethinking of the place and role of knowledge, information, information technology in the system of public administration, including - information and analytical support of public administration in the field of insurance, is extremely relevant.

The new paradigm of public administration in the information society era presupposes the transition from administrative-command forms of organization of management processes to information-structured ones, because in new conditions effective governance can be provided only by public administration decisions based on complex, systematic and logical information. Information resources and 
information processes in general become the main prerequisites for the effective functioning of public administration systems. This requires public authorities to implement systems and structures of information and analytical support of government agencies, the use of new forms and technologies of information use, new technologies for its collection, processing and analysis, creation and interaction of information databases and more.

In modern conditions, any decision-making of public administration and construction of a strategic course of development of the state and society should be based on proper information and analytical support, preliminary development of alternatives to such decisions and qualified assessment of each of them.

The subject of public administration, the head of the authority, should always take into account the probability of the emergence of new aspects of the problem situation, as well as the possibility of new problem situations in the course or as a result of the management decision. Thus, the effectiveness of public administration decisions and processes of public administration in general at the present stage directly depends on the availability and quality of functioning of systems, services and structural units for information and analytical support.

The essence and content of public administration in the field of insurance. Carrying out administrative reform, changing the basic principles of building domestic administrative and legal institutions, implementing European principles and standards of public administration make it necessary to review and reassess the importance of public administration in regulating public relations, in particular in the field of insurance. After all, insurance is an integral attribute of modern life, which, firstly, provides reliable protection of property interests of individuals and legal entities through the implementation of a mechanism to prevent or reduce the consequences of predictable or unforeseen events (insured events); secondly, having great investment opportunities and significant potential for national and regional innovation and investment programs, contributes to the continuous reproduction and development of the economy; third, being an important component of the financial system, acts as a guarantor of financial stability and economic security of the state as a whole. However, such a role of this institution becomes possible only with the appropriate level of development of the insurance market and effective state regulation of insurance activities, in which the coordinated actions of public administration aimed at regulating relations between insurance market participants are of paramount importance.

Despite the fact that public administration has become widespread in recent years, today it should be noted the lack of a legislative definition of this concept. Therefore, it is necessary in the study to study the scientific developments of scientists, which highlights public administration as a systemic phenomenon that has 
specific societal values to ensure the provision of administrative services in accordance with European standards by implementing the principles of democratic governance.

In particular, V. Kolpakov, considering the forms of public administration, defines public administration as the activity of public administration entities to implement their functions within the established competence [1, p. 43].

Public administration is a close concept to public administration and some researchers often identify them. However, agreeing with the opinion of V. Martynenko, it should be noted that public administration is a form of public administration, which is carried out by representative bodies of democratic governance through their executive structures [3, p. 20-21]. Supporting this position, $\mathrm{K}$. Kolesnikov notes that public administration is a component of public administration, the purpose of which is to ensure the democratic development of the state and society at the level of world standards through the use of the latest management methods and technologies [4, p. 44].

N. Obushna, substantiating the theoretical foundations of public administration as a qualitatively new model of public administration, emphasizes that public administration was the basis of the mechanism of implementation in practice of classical management theory in the public sector, which preceded the emergence of modern management theory. which is reduced to the effective functioning of the entire system of political institutions. At the same time, the peculiarities of public administration are ensuring the implementation of government decisions through the use of democratic, public, liberal forms and methods of managing social and economic development of society, which is only part of public administration $[5, \mathrm{p}$. 54-58].

Sometimes scientific sources use two approaches to define public administration: 1) in the narrow sense, when public administration is understood as a professional activity of civil servants, which includes all activities aimed at implementing government decisions, studying, developing and implementing government policies; 2) in a broad sense, public administration is seen as a coordinated action of the legislature, the executive and the judiciary on public affairs, which differs significantly from private sector administration, but involves a significant number of private groups and individuals working in different companies or communities; are important in shaping public policy and are part of the political process. It is in a broad sense that the concept of "public administration" in the modern domestic scientific literature corresponds to the concept of "public administration" [6, p. 4].

In the theory of public administration, public administration is presented as: a kind of management activities of public authorities, through which the state and civil 
society provide self-government (self management) of the entire social system and its development in a certain direction [7, p. 488]; management activities of executive authorities, local governments, other public authorities, which provides influence on the social system as a whole through appropriate forms, mechanisms, tools and procedures, while ensuring the movement of the social system and its development in the necessary direction [8, p. . 149].

Thus, public administration in the field of insurance is an important component of public administration, the content of which is the activities of public administration, aimed at implementing laws and other regulations by making administrative decisions to ensure the interests of insurance entities and providing statutory administrative services to insurance market participants.

In the field of insurance, a significant number of entities are endowed with public administration powers. Analysis of the nature of these powers and taking into account the extent of their impact on the insurance industry allows to distinguish between general and special subjects of public administration in this area. Common subjects include the President of Ukraine, the Verkhovna Rada of Ukraine, the Cabinet of Ministers of Ukraine, ie those subjects of public administration that determine the general principles of socio-economic development of the state, the main directions of state policy and legal principles of regulation of insurance relations. and approval of insurance market development programs, control the financing of these programs, etc. The main tasks of the general subjects of public administration in the field of insurance are the implementation of their rule-making activities and the performance of control and supervisory functions.

The activities of special subjects of public administration are directly related to the implementation of state policy in the field of insurance at all levels (national, regional, local). Such entities may include the authorized body exercising state supervision over insurance activities, the Ministry of Finance of Ukraine, the State Regulatory Service of Ukraine and other state bodies and local governments whose activities are aimed at providing administrative services to insurance market entities, conducting inspections activities of insurance organizations in order to improve analytical and information-accounting support, information-advisory work, etc.

Despite the active changes as a result of measures to optimize the system of central executive bodies, one of the problems of public administration is the duplication of the same powers, which leads to irrational use of human resources, significant financial costs, development of identical regulations and operational documentation, and in general to reduce the efficiency of the system of public administration in the field of insurance. According to the Draft Law of Ukraine "On Amendments to Certain Legislative Acts of Ukraine Concerning Consolidation of Functions on State Regulation of Financial Services Markets” № 2413a dated 
20.07.2015, the functions of control and supervision over the insurance market are to be transferred to the National Bank of Ukraine. The analysis of this bill shows that the reform of the system of state regulation of the financial market of Ukraine meets modern global trends of consolidation of control and supervisory functions in a single institution and is the basis that creates conditions for economic growth and implementation of tasks towards integration into the European and world community. However, these changes need to be implemented only in an evolutionary way, which will allow a gradual transition to a system of mega-regulation by strengthening financial services markets, universalizing financial institutions, unifying regulatory and supervisory rules, and eliminating legal conflicts and contradictions between a number of laws and conditions of state regulation of the financial sector of the economy.

European principles of administrative law play an important role in the transformation of administrative and legal institutions and the reform of the public administration system. Despite the fact that these principles have received only a fragmentary consolidation at the legislative level (for example, in the Code of Administrative Procedure of Ukraine of 06.07.2005), they are recognized at the doctrinal level and form the basis for implementing democratic standards of public administration, in particular insurance [9, p. 128]. Their perception in the legal field contributes to the effective implementation of the "human-centric" concept of state activity, which provides for the priority and ability of people to exercise their rights in relations with public administration, which ensures an appropriate level of relations between public authorities and individuals.

Examining the content of public administration in the field of insurance, it should be noted that the activities of public administration entities can be expressed in both legal and non-legal form. Legal forms of public administration in the field of insurance include those whose use causes legal consequences (for example, the adoption of regulations and individual acts on insurance, establishing rules for the formation, accounting and placement of insurance reserves and reporting indicators, registration and other significant actions). Non-legal forms include those whose use has no direct legal significance (for example, conducting audits, various meetings, consultations by public administration entities authorized to act in the field of insurance) [1, p. 47-48].

In carrying out their activities in the process of regulating insurance relations, public administration entities use a variety of administrative and legal means, ie the whole set of techniques and methods necessary to implement state policy in the field of insurance and protect the rights and interests of insurance market participants. Among the administrative and legal means of public administration in the field of insurance, registration and control means are of special importance. 
The peculiarity of the use of registration tools by public administration entities is due to the fact that insurance activities are possible only after registration of the insurance company and obtaining a permit (license) for the relevant type of insurance in public administration bodies or their structural units. Registration activities within the public administration in the field of insurance are carried out in order to officially recognize the legality of the insurance organization, giving insurers rights and responsibilities, accounting for insurance reserves, etc.

Equally important are the control tools of public administration in the field of insurance, because control and supervision, which is closely related to it, are aimed at ensuring sustainable development of the insurance market and the efficiency of insurance activities, which, in turn, significantly affects the organization of market competitive relations, achievement of economic, social and other goals of the state. Implementation of control means by public administration bodies and their structural subdivisions ensures inspections of correctness of application of insurance legislation by subjects of insurance activity and reliability of their reporting, control over insolvency of insurers in accordance with their insurance obligations to policyholders.

\section{Mechanisms of information and analytical support of public administration} in the field of insurance. Management activities in the field of insurance are carried out by issuing organizational and administrative documents. Documentation is used as a way and means of implementing management functions. In this case, the documents contain information that must be securely stored for some time.

Recently, the management functions have become significantly more complicated and the scope of tasks assigned to insurance bodies has increased, and the requirements for the quality of documents are changing. At the same time, information technologies are being actively introduced as a means of automating processes related to documented information. In addition, new legal objects have appeared in the legislation - electronic document and electronic digital signature, new forms of relations based on electronic document circulation are being developed.

On the agenda in Ukraine is the issue of intensifying the introduction and development of electronic public administration in all spheres of society, one of the important components of which is electronic document management. This will allow to obtain such important qualities of public administration as the efficiency of electronic documents exchange, the possibility of their remote processing, approval and signing, will ensure the accumulation and general availability of arrays of documents, will make it natural to create and use electronic archives.

The basis of information and analytical support of the organization is primarily the processing of documents that are subject to creation, recording and accounting in a certain form. 
Documents are used in various fields of knowledge, areas of human activity and social life. They are the object of study of various scientific disciplines and therefore the concept of the document is ambiguous and depends on in what field and for what it is used.

For the introduction of electronic document management before insurance companies, first of all, the task of creating a regulatory framework that ensures its implementation through proper organization of relevant processes and compliance with requirements for paperwork, unification of organizational and administrative documentation systems, development of a single state system of office work, a single system management documentation, etc. It should also be the basis for the settlement of relations between entities in such qualitatively new areas of activity as ecommerce, e-commerce, electronic reporting, provision of electronic (administrative) services through specialized information systems and public networks, including the Internet.

To this end, two basic laws of Ukraine were adopted: "On electronic digital signature" [10] and "On electronic documents and electronic document management" [11]. It should be noted that the provisions of the first of these laws meet the requirements of Directive 1999/93 / EC of the European Parliament and of the Council of 13 December 1999 on the system of electronic signatures applicable within the Community [12]. With the adoption of these laws, subject to certain requirements, the electronic digital signature was equated in legal status to a handwritten signature (seal), established the basic organizational and legal principles of using an electronic document and the use of electronic document management.

The Law of Ukraine "On Electronic Documents and Electronic Document Circulation" [11] regulates relations related to the sending, transmission and receipt of an electronic document. In particular, the sending and transmission of an electronic document is carried out by the author or intermediary in electronic form by means of information and telecommunication systems or by sending electronic media on which this document is recorded. In this case, the electronic document is considered to be received by the addressee from the time of receipt of the author's notice in electronic form from the addressee of its receipt, unless otherwise provided by law or prior agreement between the subjects of electronic document management. Verification of the integrity of an electronic document is performed by verifying the authenticity of the electronic digital signature imposed on it.

In pursuance of these laws, the Cabinet of Ministers of Ukraine adopted a number of resolutions that specified the regulation of relations in this area, in particular:

- "On approval of the Procedure for certifying the availability of an electronic document (electronic data) at a certain point in time" [13]; 
- "On approval of the Procedure for accreditation of the key certification center" [14];

- "On approval of the Regulations on the central certification body" [15];

- "On approval of the Procedure for the use of electronic digital signatures by public authorities, local governments, enterprises, institutions and organizations of state ownership" [16];

- "On approval of the Standard procedure for electronic document management in the executive branch" [17];

- "On approval of the Procedure for mandatory transfer of documented information" [18].

These regulations, among others, are aimed at creating and developing in Ukraine public key infrastructure (PKI - Public Key Infrastructure) to ensure the use of electronic digital signature, especially the creation of its subjects - the central certification authority and regulatory authority, as well as certification authorities. Creation and maintenance of activity of other subjects of this infrastructure - the centers of certification of keys, including the accredited centers of certification of keys, is carried out by representatives of business.

Approved by the Resolution of the Cabinet of Ministers of Ukraine "Standard procedure for electronic document management in the executive branch" [17] establishes general rules for documenting management activities in electronic form and regulates the implementation of electronic documents from the moment of their creation or receipt to send or transfer to the appropriate archive. In this case, all other actions with electronic documents are performed in the authority in accordance with the requirements for actions with documents on paper, provided by the instructions on the records of this body. The Standard Procedure applies to all electronic documents created or received by a public authority.

In this case, each insurance company, regardless of ownership, specifies for its needs the general rules of documentation in electronic form and regulates the performance of actions with electronic documents in accordance with the law.

Enterprises, institutions and organizations carry out electronic document management only if they use reliable means of electronic digital signature, which must be confirmed by a certificate of conformity or a positive opinion on the results of state examination in the field of cryptographic protection of information received from the State Special Communications Administration. public key certificates from their signatory employees. In this case, electronic document management is carried out through special telecommunications networks or public telecommunications networks, and the sending of electronic documents through public telecommunications networks is carried out by the decision of the head of this body.

According to the law, the electronic document management system must meet the requirements of regulations in the field of information protection. In particular, 
this applies to the provisions of the Law of Ukraine "On Information Protection in Information, Telecommunication and Information-Telecommunication Systems" [19] and the Resolution of the Cabinet of Ministers of Ukraine "On Approval of Rules for Information Protection in Information, Telecommunication and InformationTelecommunication Systems" [20].

Creation of archives of electronic documents, their submission to archival institutions of Ukraine and storage in these institutions is carried out in the order determined by the legislation. In particular, the order of the State Committee of Archives of Ukraine approved the "Procedure for storage of electronic documents in archival institutions" [21].

Unified mandatory information security standards have not yet been introduced for insurance companies in Ukraine, although such standards have long been applied by foreign insurers. Given that the information security policy of banking institutions is developed independently, today domestic insurers, based on foreign experience and experience in implementing information security policy in banking and other activities, as well as international information security standards, can independently develop their own information security policy.

Among the international standards of information security (ISO / IEC 27001 and ISO / IEC 27002), the information security policy is described by the standard ISO / IEC 27002, the latest version of which was released in 2013. The ISO / IEC 27001 standard is used to implement the information security management system. It prescribes the algorithms according to which the information security system should be implemented [22], while ISO / IEC 27002 provides explanations, describes in detail the steps for system implementation, includes recommendations and explanations for the prompt and correct implementation of all requirements [23]. In case of introduction of the information security system the company receives the certificate on assignment of the standard ISO / IEC 27001.

To improve and enhance the effectiveness of administrative and legal regulation of compulsory civil liability insurance of motor vehicle owners, we propose to change the outdated procedures of interaction and build a mutually beneficial partnership between insurers and policyholders, increase the level of social protection of car owners.

In December 2017, the Motor Transport Insurance Bureau offered a new possibility to quickly resolve the accident without the need to call the police - an electronic European protocol. From now on, every driver can settle the insured event by filling in a simple electronic form of the European protocol from his phone or tablet. Automating this process can significantly reduce the settlement time for drivers involved in the accident and reduce the burden on the police and the judiciary. 
In February 2018, an electronic policy of compulsory civil liability insurance for land vehicle owners was launched in Ukraine. Each driver was given the opportunity to enter into a contract directly via the Internet without having to carry a policy form. In total, more than 16,000 electronic policies have been concluded. However, the possibility of concluding an electronic contract is still not enshrined in the relevant law, but is regulated through other bylaws.

The introduction of the system of operative verification of information on the insurance coverage of a car owner by the National Police of Ukraine in the development and implementation of an electronic policy is an effective process of information exchange, which on the one hand will strengthen the car owner's confidence as insurance protection. without additional requests to the central database of the Motor (transport) insurance bureau.

Reforming public administration in the field of insurance through the introduction of digitalization. The model of public administration that was formed in Ukraine during independence remains overly centralized. To change the existing management paradigm, it is necessary to implement systemic reforms aimed at decentralization. Decentralization is characterized by the transfer of power to the local level in order to improve the quality of public services to citizens. Such a largescale modernization of the public administration system requires balanced approaches and solutions.

For the effective reform of public administration in the direction of decentralization, the political vision of the goals, objectives and mechanisms of such reform becomes crucial. We can agree that during the period that has passed since the years of Ukraine's independence, significant changes have taken place both in the system of state power and at the level of civil society. Such transformational changes require further steps to reform public administration in the new realities. An updated software and conceptual support for its implementation is needed. There is a need for significant theoretical and methodological development and rethinking of many areas of public administration reform. Given that some measures in the field of public reform have been implemented, but over time have lost their relevance, there is a need to significantly adjust strategic and tactical approaches to public reform in a decentralized environment. The task of public administration reform in the context of decentralization should be not only to change the functions and structure of the public authority, but also to radically change the entire system of public administration in Ukraine, to identify and implement mechanisms for continuous improvement and self-improvement of public administration.

The creation of digital infrastructures is a major factor in expanding citizens' access to the global information environment and knowledge. In 2011, free access to the Internet was recognized by the UN as a fundamental human right - digital law. 
Therefore, the need for access to information on administrative services and the possibility of influence and legal support must be provided by the authorities and is the basis of public administration.

The interaction between public authorities and the citizen should be based on the openness and quality of services provided by the state and is impossible without appropriate technological support, which is evolving from informatization to digitalization of public administration.

The creation of digital infrastructures is a major factor in expanding citizens' access to the global information environment and knowledge. In 2011, free access to the Internet was recognized by the $\mathrm{UN}$ as a fundamental human right - digital law. Therefore, the need for access to information on administrative services and the possibility of influence and legal support must be provided by the authorities and is the basis of public administration.

The interaction between public authorities and the citizen should be based on the openness and quality of services provided by the state and is impossible without appropriate technological support, which is evolving from informatization to digitalization of public administration.

Ukraine demonstrates insufficient progress in the transition of e-government to digitalization of public administration and harmonization of digital markets towards achieving the goals proposed by the EU for the Eastern Partnership countries in the Joint Working Document "Eastern Partnership - 20 Expected Results by 2020" [5]. In this situation, in order to move to practical and effective actions in all areas of digital harmonization in Ukraine, a set of strategic documents should be developed, synchronized with each other and supported by careful analysis.

In the legal field, the introduction of digital governance in Ukraine is defined by the Concept of Development of Digital Economy and Society of Ukraine for 20182020, which was approved by the Cabinet of Ministers of Ukraine dated January 17, 2018 №67-r and can be considered a plan of action and digital agenda of Ukraine.

This Concept is a short-term and initial tool for the development and stimulation of domestic markets for consumption, implementation and production of digital technologies, contains a vision of economic transformation from traditional to efficient digital.

It identifies priority steps to implement appropriate incentives, create conditions for digitalization in various sectors of the economy and public life, challenges and tools for digital infrastructure development, acquisition of digital competencies by citizens, and identifies critical areas and projects of public administration. Prior to the adoption of this Concept, these provisions were developed by scientists and practitioners in this field during the preparation and continuation of work on the implementation of the project "Digital Agenda of Ukraine - 2020". 
A new generation of talented, ambitious and patriotic Ukrainians, with the help of Western partners who have already passed this path and are helping to implement it in Ukraine, is developing and implementing tools for public control over service activities and digitalization of public administration.

In particular, the EGOV4Ukraine project will improve the process of providing public services at these levels through the development and implementation of the state data exchange system "Trembita" and the information system for administrative service centers "Vulyk". These information and communication technologies will make the work of public administration more transparent and efficient, and the process of providing such services and access to databases more efficient, easy and transparent.

Summing up, it should be noted that public administration in the field of insurance is an important component of public administration, the content of which is the activities of public administration to ensure the interests of insurance entities and provide statutory administrative services to insurance market participants through administrative acts (adoption regulations and operational acts, conducting audits, consultations, etc.). In the process of carrying out their activities, public administration entities perform a number of functions, including regulatory (development and adoption of regulatory and methodological documents on insurance activities), control (control and supervision of insurance companies) and organizational ( defining the principles of the insurance market and the organization of relations between participants in insurance relations), which ensures the regulation of relations between insurance market participants and other participants in insurance relations, sustainable development of insurance activities and generally contributes to democratization of social processes at world standards.

\section{References:}

1. Kolpakov V. K. Ponyattya form publichnoho administruvannya [The concept of forms of public administration]. Administratyvne pravo i protses [Administrative law and law]. 2012. № 2(2). P. 43-51.

2. Chernov S. I. Tekst lektsiy $z$ dystsypliny «Publichne administruvannya» [Text of lectures on the discipline "Public Administration]. Kh.: KhNUMH, 2014. 97 p.

3. Martynenko V. M. Demokratychne vryaduvannya: problemy teoriyi ta praktyky. Publichne upravlinnya: teoriya ta praktyka: zb. nauk. pr. [Democratic governance: problems of theory and practice] 2010. № 1. P. $16-22$.

4. Kolesnykova K. O. Spivvidnoshennya derzhavnoho upravlinnya ta publichnoho administruvannya $u$ protsesi suspil'noyi transformatsiyi [The ratio of public administration and public administration in the process of society new transformation]. Publichne upravlinnya: teoriya ta praktyka [Public administration: theory and practice]. 2013. Vyp. 3. P. 41-45.

5. Obushna N. I. Publichne upravlinnya yak nova model' orhanizatsiyi derzhavnoho upravlinnya v Ukrayini: teoretychnyy aspekt [Public administration as a new model of public administration in Ukraine: theoretical aspect]. Efektyvnist' derzhavnoho upravlinnya [Effectiveness of public administration]. 2015. Vyp. 44(1). P. 53-63.

6. Mel'tyukhova N. M., Korzhenko V. V., Didok Yu. V. [ta in.] Zarubizhnyy dosvid publichnoho administruvannya: metod. rek. [Foreign experience of public administration: method. rivers]. K.: NADU, 2010. $28 \mathrm{p}$. 
7. Kovbasyuk Yu. V. [ta in.] Entsyklopediya derzhavnoho upravlinnya: $u 8$ t. [Encyclopedia of public administration: in 8 volumes] K.: NADU, 2011. T. 8.630 p.

8. Kruhlov V. V. Publichne administruvannya $v$ protsesi derzhavno-pryvatnoho partnerstva [Public administration in the process of public-private partnership]. Aktual'ni problemy derzhavnoho upravlinnya [Act problems of public administration]. 2015. № 1. P. 145-153.

9. Averyanova V. B., Pukhtets'ka A. A. Yevropeys'ki pryntsypy administratyvnoho prava: Monohrafiya [European principles of administrative law: Monograph]. K.: Instytut derzhavy i prava im. V. M. Korets'koho [Institute of State and Law. VM Koretsky], 2012. 237 p.

10. Pro elektronnij cifrovij pidpis : Zakon Ukrayini vid 22 travnya 2003 r. № 852-IV [On electronic digital signature: Law of Ukraine from May 22, 2003 № 852-IV]. URL: http://www.rada.gov.ua

11. Pro elektronni dokumenti ta elektronnij dokumentoobig : Zakon Ukrayini vid 22 travnya 2003 r. № 851 IV [About electronic documents and electronic document flow: Law of Ukraine of May 22, 2003 № 851-IV]. URL: http://www.rada.gov.ua

12. Direktiva 1999/93/ES Yevropejskogo Parlamentu ta Radi vid 13 grudnya 1999 roku "Pro sistemu elektronnih pidpisiv, sho zastosovuyetsya v mezhah Spivtovaristva" (DIRECTIVE 1999/93/EC OF THE EUROPEAN PARLIAMENT AND OF THE COUNCIL of 13 December 1999 on a Community framework for electronic signatures, Oficijnij zhurnal L 013, 19/01/2000 p. 0012 - 0020. Pereklad zdijsneno Centrom perekladiv aktiv Yevropejskogo prava pri ministerstvi yusticiyi Ukrayini) [Directive 1999/93 / EC of the European Parliament and of the Council of December 13, 1999 "On the system of electronic signatures that applicable within the Community"(DIRECTIVE 1999/93 / EC OF THE EUROPEAN PARLIAMENT AND OF THE COUNCIL of 13 December 999 on a Community framework for electronic signatures, Official Journal L 013, 19/01/2000 p. 0012 - 0020. Translated by the Center translations of acts of European law at the Ministry of Justice of Ukraine)]. URL: http://uazakon.com/document/spart50/inx50337.htm.

13. Pro zatverdzhennya Poryadku zasvidchennya nayavnosti elektronnogo dokumenta (elektronnih danih) na pevnij moment chasu : Postanova Kabinetu Ministriv Ukrayini vid 26 travnya 2004 r. № 680. [About the statement of the Procedure for certification of existence of electronic document (electronic data) at a certain point in time: Resolution Of the Cabinet of Ministers of Ukraine of May 26, 2004 № 680]. URL: http://www.rada.gov.ua.

14. Pro zatverdzhennya Poryadku akreditaciyi centru sertifikaciyi klyuchiv : Postanova Kabinetu Ministriv Ukrayini vid 13 lipnya 2004 r. № 903 [On approval of the Procedure for accreditation of the certification center keys: Resolution of the Cabinet of Ministers of Ukraine of July 13, 2004 № 903]. URL: http://www.rada.gov.ua.

15. Pro zatverdzhennya Polozhennya pro centralnij zasvidchuvalnij organ : Postanova Kabinetu Ministriv Ukrayini vid 28 zhovtnya 2004 r. № 1451 [On approval of the Regulations on the central certification body: Resolution of the Cabinet of Ministers of Ukraine of October 28, 2004 № 1451]. URL: http://www.rada.gov.ua.

16. Pro zatverdzhennya Poryadku zastosuvannya elektronnogo cifrovogo pidpisu organami derzhavnoyi vladi, organami miscevogo samovryaduvannya, pidpriyemstvami, ustanovami ta organizaciyami derzhavnoyi formi vlasnosti : Postanova Kabinetu Ministriv Ukrayini vid 28 zhovtnya 2004 r. № 1452 [About the statement of the Order of application of electronic digital signature by public authorities, local authorities self-government, enterprises, institutions and organizations of the state forms of ownership: Resolution of the Cabinet of Ministers of Ukraine of October 282004 № 1452]. URL: http://www.rada.gov.ua.

17. Pro zatverdzhennya Tipovogo poryadku zdijsnennya elektronnogo dokumentoobigu $v$ organah vikonavchoyi vladi : Postanova Kabinetu Ministriv Ukrayini vid 28 zhovtnya 2004 r. № 1453 [On approval of the Standard procedure for electronic implementation document circulation in executive bodies: Resolution of the Cabinet Minister of Ukraine of October 28, 2004 № 1453]. URL: http://www.rada.gov.ua.

18. Pro zatverdzhennya Poryadku obov'yazkovoyi peredachi dokumentovanoyi informaciyi : Postanova Kabinetu Ministriv Ukrayini vid 28 zhovtnya 2004 r. № 1454 [On approval of the Procedure for mandatory transfer documented information: Resolution of the Cabinet of Ministers of Ukraine from October 28, 2004 № 1454]. URL: http://www.rada.gov.ua.

19. Pro zahist informaciyi $v$ informacijnih, telekomunikacijnih ta informacijno-telekomunikacijnih sistemah : Zakon Ukrayini vid 5 lipnya 1994 r. № 80/94-VR [On information protection in information, telecommunications and information and telecommunication systems: Law of Ukraine of July 5 1994 № 80/94-BP]. URL: http://www.rada.gov.ua

20. Pro zatverdzhennya Pravil zabezpechennya zahistu informaciyi v informacijnih, telekomunikacijnih ta informacijno-telekomunikacijnih sistemah : Postanova Kabinetu Ministriv Ukrayini vid 29 bereznya $2006 r$. № 373 [About the statement of Rules of maintenance of protection of the information in information, 
telecommunication and information-telecommunication systems: Resolution of the Cabinet of Ministers of Ukraine of March 29, 2006 № 373]. URL: http://www.rada.gov.ua.

21. Pro zatverdzhennya Poryadku zberigannya elektronnih dokumentiv $\mathrm{v}$ arhivnih ustanovah : Nakaz Derzhavnogo komitetu arhiviv Ukrayini vid 25 kvitnya 2005 r. № 49 [About the statement of the Order of storage of electronic documents in archival institutions: Order of the State Committee of Archives of Ukraine from April 25, 2005 № 49]. URL: http://www.rada.gov.ua.

22. Domarev V.V. Bezpeka informacijnih tehnologij. Metodologiya stvorennya sistem zahistu [Information technology security. Methodology creation of protection systems]. URL: http://domarev.kiev.ua.

23. Dreshpak VM Informacijno-analitichne zabezpechennya organiv miscevoyi vladi : navch. posib. / V. M. Dreshpak, T. M. Brus, O. V. Tinkovan ta in. ; za zag. red. V. M. Dreshpaka ; Nac. akad. derzh. upr. pri Prezidentovi Ukrayini, Dnipropetr. region [Information and analytical support of organs local government: textbook. way. Nat. acad. state at To the President of Ukraine, Dnipropetrovsk. region]. Dnipropetrovsk: DRIDU NADU, 2007. 159 p. 